\title{
Chemometric Research of Minerals and Trace Elements in Selected Malaysian Local Fruits using Inductively Coupled Plasma Optical Emission Spectroscopy (ICP-OES)
}

\author{
Khalilah Badarusham, Nurul Elma Sabri, Shamala Salvamani, Mohd Sukri Hassan, Zaiton \\ Hassan, Roshada Hashim
}

\begin{abstract}
Malaysia is a tropical country that has a rich diversity of fruits. Fruits are sources of many essential elements, proximate composition and minerals that play vital roles in the proper development and good health of the human body. This study aimed at evaluating the content of mineral elements; macro and micro elements. Fruit samples were obtained from the local farm located at Bagan Datuk, Perak, Malaysia. The results obtained by chemical analysis were evaluated statistically with the majority of the fruit samples were rich in some of the essential minerals like sodium, potassium, calcium, iron, magnesium, copper, manganese and zinc. The data were subjected to chemometric assessment to understand the association between the elements concentration and to classify the fruit samples according to their minerals content. The principal components analysis (PCA) clearly showed a good separation of samples in terms of mineral constituents. The results fall within the limits.
\end{abstract}

Index Terms:- Inductively Coupled Plasma Optical Emission Spectroscopy (ICP-OES), local fruits, mineral elements, Principal Components Analysis (PCA).

\section{INTRODUCTION}

Fruits, including vegetables are indispensable part of human diet. In a world faced with food shortage, they are generally acceptable as a good source of nutrient and supplement [1]. The constituents of biological active substances in fruit give beneficial effects on human health such as antioxidants, anticarcinogens, antimutagens and antibacterial [2]. Fruits are known to be excellent source of nutrients, such as vitamins and minerals. Fruits provide a varied flavoured, tasty, colourful, low caloric, protective and micronutrient rich diet [3]. The protective effect is enhanced probably through the action of micronutrients and antioxidants such as flavonoids, carotenoids, folic acid and

Revised Manuscript Received on July 10, 2019

Khalilah Badarusham, Faculty of Science and Technology, Universiti Sains Islam Malaysia, 71800, Bandar Baru Nilai, Negeri Sembilan, Malaysia.

Nurul Elma Sabri, Faculty of Science and Technology, Universiti Sains Islam Malaysia, 71800, Bandar Baru Nilai, Negeri Sembilan, Malaysia.

Shamala Salvamani, Division of Applied Biomedical Science and Biotechnology, School of Health Sciences, International Medical University, 57000 Bukit Jalil, Kuala Lumpur, Malaysia

Mohd Sukri Hassan, Faculty of Science and Technology, Universiti Sains Islam Malaysia, 71800, Bandar Baru Nilai, Negeri Sembilan, Malaysia.

Zaiton Hassan, Faculty of Science and Technology, Universiti Sains Islam Malaysia, 71800, Bandar Baru Nilai, Negeri Sembilan, Malaysia.

Roshada Hashim, Faculty of Science and Technology, Universiti Sains Islam Malaysia, 71800, Bandar Baru Nilai, Negeri Sembilan, Malaysia. vitamin $\mathrm{C}$, as well as dietary fibre which are abundant in fruits and vegetables [4]. In [5] reported the 6th main risk factor for mortality is due to the low consumption of fruits and vegetables [4], [6] which also lead to the risk of obesity, heart disease and stroke [7]. Recommended daily intake of fruits and vegetables is $4400 \mathrm{~g} /$ day which can help to prevent major non-communicable disease [8] like cancers and cardiovascular disease [9]. Researchers have proved that fruits and vegetables are rich sources of nutrients as well as non-nutrient molecules with antioxidant or other physiological effects and sufficient bioavailability, these compounds may be important constituents of a healthy diet [1].

Unfortunately, it has been reported that majority of people regularly consume less fruits and vegetables than the daily recommended requirement [3]. In [7] had done a survey for 52 low- and middle-income countries, and revealed that 78.4 $\%$ of women and $77.6 \%$ of men consumed less than minimum recommended five daily serving of fruits and vegetables. The lower intake of fruits and vegetables may lead to the high prevalence of malnutrition, especially micro nutrient deficiencies and diet-related noncommunicable diseases. Adequate intake of important micro nutrients is proven to prevent some disease, besides play a crucial role in numerous biochemical and physiological processes of the body. Nutrients such as proteins, carbohydrates, vitamins, minerals and water are vital for human health [10]. Some elements such as copper $(\mathrm{Cu})$, iron $(\mathrm{Fe})$ and zinc $(\mathrm{Zn})$ help to combat infection [11] but they are also associated with many chronic, epidemic, endemic, and even malignant diseases [1]. Nowadays, the deficiency of vitamins and minerals become one of the major human health problem. For instance, the deficiency of $\mathrm{Fe}$ causes anemia which affected one third of world population [12]. Trace elements are required components for enzyme.

The deficiency of trace elements will produce a characteristics syndrome which reflects the specific functions of the nutrient in the metabolism of the animal [13]. Fruits and vegetables possess low energy content with very high densities of nutrient. Foods which are high in composition of saturated fats, salt and sugar can be replaced with the intake of fruits and vegetables. 


\section{CHEMOMETRIC RESEARCH OF MINERALS AND TRACE ELEMENTS IN SELECTED MALAYSIAN LOCAL FRUITS USING INDUCTIVELY COUPLED PLASMA OPTICAL EMISSION SPECTROSCOPY (ICP- OES)}

Subsequently, this improve the consumption of most micro nutrients and dietary fibre. Furthermore, it is a must to observe the level of toxic content such as cadmium $(\mathrm{Cd})$, lead $(\mathrm{Pb})$, mercury $(\mathrm{Hg})$ and nickel $(\mathrm{Ni})$ in food [8]. Malaysia is one of the countries that has a rich diversity of underutilized fruits that grow abundantly in the region of Peninsular Malaysia. Namnam (Cynometra sp.) bacang (Mangifera sp.), durian (Durio sp.), bidara (Ziziphus sp.), assam kelubi (Salacca sp.), belimbing buloh (Averrhoa sp.), carambola (Averrhoa carambola) and sentol (Sandoricum sp.) are among the underutilized fruits commonly consumed and widely cultivated in Malaysia [14], [15]. They are commonly planted in orchards or fruit gardens around houses and some grow wild in the rain forest. The nutritional and medicinal properties of these fruits are commonly known by older folks [16]. The lack of good database and poor knowledge on the nutrient composition and quality of traditional food crops are some of the reasons for low fruit and vegetable consumption in developing countries, especially in younger generation.

Various analytical techniques like graphite furnace atomic absorption spectroscopy (GFAAS) and flame atomic absorption spectroscopy (FAAS) have been used to quantify the heavy metals $(\mathrm{Cd}, \mathrm{Pb} \mathrm{Hg}$ and $\mathrm{Ni})$ in plant materials and food samples. [13], [17]. Inductively coupled plasma optical emission spectrometry (ICP-OES) is one of the instrument which is reported the most frequently used with a very good detection limit [18] and many samples can be run at a time compare to atomic absorption spectrometry (AAS) [8], [19]. Besides that, it has characteristics such as high sensitivity and lower chemical interference [20]. Principal components analysis (PCA) is a powerful mathematical tool that can be used to reduce the dimensionality of a data set consisting of a large number of interrelated variable, which allows to visualize the underlying structure of the experimental data and the relationships between samples and data [1]. This reduction generates a new reduced and uncorrelated set of variables, called principal components. Thus, these components are chosen to ensure that the former retain the greater part of the variance present in the original variables [21].

Hence, the aim of this study was to evaluate the elements composition of a variety of Malaysian local fruits using ICPOES, analysis of variance (ANOVA) and PCA analyses. This information would give the Malaysian a better understanding of the mineral compositions of local fruits, especially to the underutilized species.

\section{MATERIALS AND METHOD}

\section{A. Chemical Reagents and Solution}

All chemicals used throughout the experiments were of analytical reagent grade (Merck, Darmstadt, Germany). Ultrapure water $\left(18.2 \mathrm{M} \Omega . \mathrm{cm}^{-1}\right)$ from a Mili-Q system (Millipore, MA, USA) was used to prepare all the solutions. The standard solutions for calibration purposes were prepared by diluting the stock solutions $\left(1000 \mathrm{mg} \mathrm{L}^{-1}\right)$ of the investigated standard elements; Barium (Ba), calcium $(\mathrm{Ca})$, copper $(\mathrm{Cu})$, iron $(\mathrm{Fe})$, potassium $(\mathrm{K})$, magnesium $(\mathrm{Mg})$, manganese $(\mathrm{Mn})$, nickel $(\mathrm{Ni})$, lead $(\mathrm{Pb})$, zinc $(\mathrm{Zn})$, selenium $(\mathrm{Se})$, aluminium ( $\mathrm{Al})$ and sodium $(\mathrm{Na})$. All the glassware was cleaned by soaking in dilute nitric acid solution for 12

hour for decontamination and then rinsed several times with deionized water prior to use. Nitric acid, $\mathrm{HNO}_{3}(65 \% \mathrm{v} / \mathrm{v})$ and hydrochloric acid, $\mathrm{HCl}(65 \% \mathrm{v} / \mathrm{v})$, were used for acid digestion.

\section{B. Sample Preparation}

Ten types of local fruit (Table 1); kedondong (Averrhoa carambola L.), jackfruit (Artocarpus heterophyllus), rokam (Flacourtia rukam), namnam (Cynometra cauliflora), banana (Musa acuminata), guava (Psidium guajava), papaya (Carica papaya), starfruit (Averrhoa carambola), pelam padi (Magnifera indica) and pelam putih (Magnifera indica) were picked manually from the farm located at Bagan Datuk, Perak, Malaysia. Each samples were washed several times with tap water followed by deionized water in order to remove dust or other particles adhering to the sample surfaces and then oven dried at $50{ }^{\circ} \mathrm{C}$ for 1 hour. The samples were then blended using a Waring blender ( 2 speed, $230 \mathrm{~V} / 50 \mathrm{~Hz}, 1 \mathrm{~L})$; National, Japan to homogenize the samples.

Table 1: Selected Malaysian local fruits

\begin{tabular}{|c|c|c|}
\hline Botanical Name & $\begin{array}{c}\text { Common/ } \\
\text { English Name }\end{array}$ & Family \\
\hline Flacourtia rukam & Rokam & Salicaceae \\
\hline Cynometra cauliflora & Namnam & Fabaceae \\
\hline Magnifera indica & Pelam putih & Anacardiaceae \\
\hline Magnifera indica & Pelam padi & Anacardiaceae \\
\hline Spondias dulcis & Kedondong & Anacardiaceae \\
\hline Artocarpus heterophyllus & Jackfruit & Moraceae \\
\hline Musa acuminata & Banana & Musaceae \\
\hline Psidium guajava & Guava & Myrtaceae \\
\hline Carica papaya & Papaya & Caricaceae \\
\hline Averrhoa carambola & Starfruit & Oxalidaceae \\
\hline
\end{tabular}

\section{Ash and Elements Determination}

Briefly, replicate samples (approximately $5.0 \mathrm{~g}$ ) were weighed and dried in the oven at $115{ }^{\circ} \mathrm{C}$ for 1 hour. They were then placed in a muffle furnace at $550{ }^{\circ} \mathrm{C}$ for 24 hour. The ash was weighed and acid digestion method was used to determine the elements constituents. Each sample was digested with a mixture of $\mathrm{HNO}_{3}(0.1 \mathrm{M}, 20 \mathrm{~mL})$ and $\mathrm{HCl}(6$ $\mathrm{M}, 5 \mathrm{~mL}$ ) at the room temperature. The solution was subsequently filtered and transferred to $50 \mathrm{~mL}$ volumetric flask. All samples were then analyzed by ICP-OES with axial viewing (Optima 4300DV, Perkin Elmer) under the conditions as stated Table 2.

Table 2: All samples analyzed by ICP-OES with axial viewing

\begin{tabular}{|c|c|}
\hline RF Power $(\mathrm{W})$ & $: 1300$ \\
\hline Plasma gas rate $(\mathrm{Ar})\left(\mathrm{L} \mathrm{min}{ }^{-1}\right)$ & $: 8.0$ \\
\hline Auxiliary gas rate $\left(\mathrm{L} \mathrm{min}^{-1}\right)$ & $: 0.2$ \\
\hline Nebulizer gas rate $\left(\mathrm{L} \mathrm{min}^{-1}\right)$ & $: 0.55$ \\
\hline Pipe flow rate $\left(\mathrm{mL} \min ^{-1}\right)$ & $: 1.5$ \\
\hline
\end{tabular}


The concentration $(\mathrm{C})$ of the mineral in the samples were then calculated using the following formula [22].

$$
C=\frac{(a-b) \times v}{m} X d f
$$

where $\mathrm{C}$ means concentration of mineral in the test sample $(\mathrm{mg} / \mathrm{kg}), \mathrm{a}=$ concentration in the experiment solution $(\mathrm{mg} / \mathrm{mL}), \mathrm{b}=$ mean concentration in the blank solutions $(\mathrm{mg} / \mathrm{mL}), \mathrm{v}=$ volume of the experiment solution $(\mathrm{mL}), \mathrm{m}=$ weight of the test portion and $\mathrm{df}=$ dilution factor.

\section{Statistical Analysis}

Significance between elements was tested with one way ANOVA using Minitab statistical software (Version 16, Minitab Inc., USA). Differences among means were considered significant at $\mathrm{p}<0.05$. Multivariate data of major and minor elements in dates-flesh and dates-pits (triplicates samples) were mean-normalized using Microsoft Excel 2007. Exploratory analysis technique using PCA was performed on the normalized data matrix using Unscrambler 10.3 (CAMO software AS, Oslo, Norway) to identify the relationship between samples studied and its elements content in scores and loadings plots.

\section{RESULTS AND DISCUSSION}

\section{A. ANOVA}

ANOVA by one way technique on dataset of ICP-OES showed significant differences among samples of local fruit. All analyses were carried out in triplicate and the results are presented in Table 2 as means \pm standard deviation (SD).

\section{B. Minerals Concentration in Local Fruit}

The elements contents of ten varieties of local fruits are summarized in Table 2. The results showed significant $(p<0.05)$ differences among the 10 varieties. The pattern concentration of minerals in samples were decreased as follows: $\mathrm{K}>\mathrm{Ca}>\mathrm{Mg}>\mathrm{Na}>\mathrm{Al}>\mathrm{Fe}>\mathrm{Zn}>\mathrm{Mn}>\mathrm{Cu}>\mathrm{Se}$ $>\mathrm{Pb}>\mathrm{Ba}>\mathrm{Ni}$. Referring to [23] minerals are classified into two types; major and minor minerals. Examples of major minerals are $\mathrm{Ca}, \mathrm{K}, \mathrm{Mg}$ and $\mathrm{Na}$ which are needed by our body in high amounts, whereas minor minerals is a group of elements that are present or needed in human body in very small amounts but nonetheless important for good health. Minor minerals include $\mathrm{Se}, \mathrm{Zn}, \mathrm{Fe}, \mathrm{Mn}$ and $\mathrm{Cu}$. These elements can also be classified as trace minerals.

\section{Macro Elements}

The minerals content of samples in Table 2 showed that $\mathrm{K}, \mathrm{Ca}, \mathrm{Mg}$ and $\mathrm{Na}$ are higher $(15 \mathrm{mg} / \mathrm{kg}-2347 \mathrm{mg} / \mathrm{kg})$ than other components hence considered as the major elements while $\mathrm{Al}, \mathrm{Fe}, \mathrm{Zn}, \mathrm{Mn}, \mathrm{Cu}, \mathrm{Se}, \mathrm{Pb}, \mathrm{Ba}$ and $\mathrm{Ni}$ were grouped as minor elements. $\mathrm{K}$ assist for muscular weakness which is associated with malaria and also for vascular muscle such as sclerosis. It contributes by fighting against bacteria and cleanses the digestive system [24]. In this study, the highest $\mathrm{K}$ content was measured in the banana $(2347 \mathrm{mg} / \mathrm{kg})$ and the lowest K content was observed in pelam putih $(431 \mathrm{mg} / \mathrm{kg})$.

Variability in Ca concentration among fruit samples were recorded with value ranging from $21.3 \mathrm{mg} / \mathrm{kg}$ to 284 $\mathrm{mg} / \mathrm{kg}$ ). The highest Ca content was observed in rokam (284 $\mathrm{mg} / \mathrm{kg})$, followed by kedondong $(175 \mathrm{mg} / \mathrm{kg})$ and guava $(110 \mathrm{mg} / \mathrm{kg})$ and the lowest of $\mathrm{Ca}$ is recorded in starfruit $(21.3 \mathrm{mg} / \mathrm{kg})$. There was a significance different $(\mathrm{p}<0.05)$ between rokam and kedondong and insignificant different noted between other samples in the range between 21.31 $\mathrm{mg} / \mathrm{kg}$ and $95.4 \mathrm{mg} / \mathrm{kg}$. In [25] performed the study of minerals in fruits and stated that papaya contains high concentration of $\mathrm{Ca}(160 \mathrm{mg} / \mathrm{kg})$ which is within the range of kedondong in this study. Cahave been recognized as the essential mineral elements in producing stronger bones and teeth. Besides that, it plays a vital role in mediating the constriction and relaxation of blood vessels, nerve impulse transmission, muscle contraction and secretion of hormone like insulin [23], [26]. People who are allergic to the food with animal- based are advised to take a supplement with plant-based Ca [27].

$\mathrm{Mg}$ level was in the range between $33.8 \mathrm{mg} / \mathrm{kg}$ to 246.8 $\mathrm{mg} / \mathrm{kg}$. The highest level of $\mathrm{Mg}$ was recorded in jackfruit $(246.8 \mathrm{mg} / \mathrm{kg})$ and the lowest was found in namnam $(33.8$ $\mathrm{mg} / \mathrm{kg}$ ). The concentration of $\mathrm{Mg}$ in jackfruit is much higher compared to the data reported by [28] with concentration of $108.3 \mathrm{mg} / \mathrm{kg}$. $\mathrm{Mg}$ plays a vital role in the absorption of $\mathrm{Ca}$ and together combine for strengthening the bone to avoid occurrence of osteoporosis [29]. Among the analysed fruit, papaya contained $131 \mathrm{mg} / \mathrm{kg}$ of $\mathrm{Na}$ and significantly $(p<0.05)$ higher than other samples and insignificantly different which is in the range between $15.5 \mathrm{mg} / \mathrm{kg}$ and 41.7 $\mathrm{mg} / \mathrm{kg}$.

Table 2: Concentration of macro and micro elements in the fruit samples

\begin{tabular}{|c|c|c|c|c|c|c|c|c|c|c|c|c|c|}
\hline Samples & \multicolumn{13}{|c|}{ Macro and Micro Concentration of Malaysian Local Fruits (mg/kg) } \\
\hline & $\mathrm{Ba}$ & $\mathrm{Ca}$ & $\mathrm{Cu}$ & $\mathrm{Fe}$ & $\mathrm{K}$ & $\mathrm{Mg}$ & $\mathrm{Mn}$ & \begin{tabular}{|l|}
$\mathrm{Ni}$ \\
\end{tabular} & $\mathrm{Pb}$ & $\mathrm{Zn}$ & $\mathrm{Se}$ & $\mathrm{Al}$ & $\mathrm{Na}$ \\
\hline Rokam & $\begin{array}{c}0.121 \pm \\
0.024^{\mathrm{a}}\end{array}$ & $\begin{array}{l}284 \pm \\
38.97^{\mathrm{a}}\end{array}$ & $\begin{array}{l}0.74 \pm \\
0.058^{\mathrm{ab}}\end{array}$ & $\begin{array}{c}1.982 \pm \\
0.329^{\mathrm{a}}\end{array}$ & $\begin{array}{l}1268 \pm \\
270.8^{\mathrm{a}}\end{array}$ & $\begin{array}{c}77.09 \pm \\
8.18^{\mathrm{cd}}\end{array}$ & $\begin{array}{l}0.651 \pm \\
0.093^{\mathrm{bc}}\end{array}$ & $\begin{array}{c}0.103 \pm \\
0.010^{\mathrm{b}}\end{array}$ & $\begin{array}{c}0.207 \pm \\
0.008^{\mathrm{a}}\end{array}$ & $\mid \begin{array}{c}3.417 \pm \\
0.471^{\mathrm{a}}\end{array}$ & $\begin{array}{c}0.344 \pm \\
0.043^{\mathrm{a}}\end{array}$ & $\begin{array}{c}5.244 \pm \\
1.295^{\mathrm{a}}\end{array}$ & $\begin{array}{c}25.99 \pm \\
6.15^{\mathrm{b}}\end{array}$ \\
\hline Namnam & $\begin{array}{c}0.068 \pm \\
0.020^{\mathrm{a}} \\
\end{array}$ & $\begin{array}{c}67 \pm \\
6.43^{\mathrm{cd}}\end{array}$ & $\begin{array}{c}0.633 \pm \\
0.029^{b}\end{array}$ & $\begin{array}{c}1.384 \pm \\
0.426^{\mathrm{a}} \\
\end{array}$ & $\begin{array}{l}682 \pm \\
18.3^{\text {cd }} \\
\end{array}$ & $\begin{array}{c}33.76 \pm \\
1.45^{\mathrm{e}} \\
\end{array}$ & $\begin{array}{l}0.215 \pm \\
0.037^{\mathrm{cd}} \\
\end{array}$ & $\begin{array}{c}0.020 \pm \\
0.010^{\mathrm{d}}\end{array}$ & $\begin{array}{l}0.159 \pm \\
0.023^{\mathrm{ab}}\end{array}$ & $\begin{array}{l}1.164 \mathrm{t} \\
0.075^{\mathrm{cd}}\end{array}$ & $\begin{array}{l}0.088 \pm \\
0.035^{\mathrm{cd}}\end{array}$ & $\begin{array}{c}3.528 \pm \\
0.564^{\mathrm{a}} \\
\end{array}$ & $\begin{array}{c}22.69 \pm \\
9.52^{\mathrm{b}}\end{array}$ \\
\hline $\begin{array}{c}\text { Pelam } \\
\text { putih }\end{array}$ & $\begin{array}{c}0.126 \pm \\
0.046^{\mathrm{a}} \\
\end{array}$ & $\begin{array}{l}95 \pm \\
3.26^{\mathrm{c}} \\
\end{array}$ & $\begin{array}{l}0.557 \pm \\
0.136^{\mathrm{b}}\end{array}$ & $\begin{array}{c}1.392 \pm \\
0.748^{\mathrm{a}} \\
\end{array}$ & $\begin{array}{l}431 \pm \\
72.0^{d}\end{array}$ & $\begin{array}{l}64.03 \pm \\
2.81^{\text {cde }} \\
\end{array}$ & $\begin{array}{l}0.608 \pm \\
0.087^{\text {bc }}\end{array}$ & \begin{tabular}{|c|}
$0.020 \pm$ \\
$0.011^{\mathrm{d}}$ \\
\end{tabular} & $\begin{array}{l}0.139 \pm \\
0.015^{\mathrm{bc}}\end{array}$ & $\begin{array}{l}0.712 \pm \\
0.032^{\mathrm{d}}\end{array}$ & \begin{tabular}{|l|}
$0.139 \pm$ \\
$0.023^{\mathrm{bc}}$ \\
\end{tabular} & $\begin{array}{c}5.436 \pm \\
0.531^{\mathrm{a}} \\
\end{array}$ & $\begin{array}{c}34.08 \pm \\
9.75^{\mathrm{b}} \\
\end{array}$ \\
\hline Pelam padi & $\begin{array}{c}0.126 \pm \\
0.012^{\mathrm{a}}\end{array}$ & $\begin{array}{c}56 \pm \\
6.75^{\mathrm{cd}}\end{array}$ & $\begin{array}{l}0.799 \pm \\
0.186^{\mathrm{ab}}\end{array}$ & $\begin{array}{c}1.686 \pm \\
0.065^{\mathrm{a}}\end{array}$ & $\begin{array}{c}654 \pm \\
121.6^{\mathrm{cd}}\end{array}$ & $\begin{array}{c}67.90 \pm \\
6.47^{\mathrm{cd}}\end{array}$ & $\begin{array}{l}0.676 \pm \\
0.1220^{\mathrm{bc}}\end{array}$ & $\begin{array}{c}0.022 \pm \\
0.003^{\mathrm{d}}\end{array}$ & $\begin{array}{l}0.121 \pm \\
0.006^{\text {bcd }}\end{array}$ & $\begin{array}{c}0.978 \pm \\
0.078^{\mathrm{d}}\end{array}$ & $\begin{array}{l}0.093 \pm \\
0.026^{\mathrm{cd}}\end{array}$ & $\begin{array}{c}4.454 \pm \\
1.220^{\mathrm{a}} \\
\end{array}$ & $\begin{array}{c}22.90 \pm \\
2.29^{\mathrm{b}}\end{array}$ \\
\hline
\end{tabular}




\section{CHEMOMETRIC RESEARCH OF MINERALS AND TRACE ELEMENTS IN SELECTED MALAYSIAN LOCAL FRUITS USING INDUCTIVELY COUPLED PLASMA OPTICAL EMISSION SPECTROSCOPY (ICP-}

OES)

\begin{tabular}{|c|c|c|c|c|c|c|c|c|c|c|c|c|c|}
\hline & $\begin{array}{c}0.056 \pm \\
0.024^{\mathrm{a}}\end{array}$ & $\begin{array}{l}175 \pm \\
24.82^{b}\end{array}$ & $\begin{array}{l}0.963 \pm \\
0.308^{\mathrm{ab}}\end{array}$ & $\begin{array}{c}1.890 \pm \\
0.282^{\mathrm{a}}\end{array}$ & $\begin{array}{c}851 \pm \\
16.9^{\text {bcd }}\end{array}$ & $\begin{array}{c}53.25 \pm \\
4.31^{\mathrm{de}}\end{array}$ & $\begin{array}{l}0.145 \pm \\
0.011^{\text {cd }}\end{array}$ & $\begin{array}{c}0.025 \pm \\
0.009^{\mathrm{d}}\end{array}$ & $\begin{array}{c}0.117 \pm \\
0.032^{\text {bcde }}\end{array}$ & $\begin{array}{l}1.084 \pm \\
0.106^{\mathrm{cd}}\end{array}$ & $\begin{array}{c}0.232 \pm \\
0.015^{\mathrm{b}}\end{array}$ & $\begin{array}{l}2.219 \pm \\
0.096^{\mathrm{a}}\end{array}$ & $\begin{array}{c}15.45 \pm \\
1.48^{\mathrm{b}}\end{array}$ \\
\hline Jack & $\begin{array}{c}0.086 \pm \\
0.008^{\mathrm{a}}\end{array}$ & $\begin{array}{l}84 \pm \\
5.14^{c}\end{array}$ & $\begin{array}{c}1.727 \pm \\
0.092^{\mathrm{a}}\end{array}$ & $\begin{array}{l}3.048 \pm \\
0.252^{\mathrm{a}}\end{array}$ & $\begin{array}{c}2172 \pm \\
87.1^{\mathrm{a}}\end{array}$ & $\begin{array}{c}246.82 \\
\pm 12.44^{\mathrm{a}}\end{array}$ & $\begin{array}{l}3.107 \pm \\
0.077^{\mathrm{a}}\end{array}$ & $\begin{array}{c}0.076 \pm \\
0.007^{\mathrm{a}}\end{array}$ & $\begin{array}{c}0.096 \pm \\
0.017^{\text {cdef }}\end{array}$ & $\begin{array}{l}1.696 \pm \\
0.130^{\mathrm{bc}}\end{array}$ & $=\begin{array}{l}0.107 \pm \\
0.062^{\text {cd }}\end{array}$ & $\begin{array}{c}5.017 \pm \\
0.305^{\mathrm{a}}\end{array}$ & $\begin{array}{c}32.49 \pm \\
3.83^{\mathrm{b}}\end{array}$ \\
\hline Banana & $\begin{array}{c}0.103 \pm \\
0.057^{\mathrm{a}} \\
\end{array}$ & $\begin{array}{c}34 \pm \\
5.54^{\mathrm{cd}}\end{array}$ & $\begin{array}{c}0.594 \pm \\
0.226^{\mathrm{b}}\end{array}$ & $\begin{array}{c}3.530 \pm \\
0.953^{\mathrm{a}} \\
\end{array}$ & $\begin{array}{l}2347 \pm \\
218.7^{\mathrm{a}}\end{array}$ & $\begin{array}{r}222.56 \\
+27.49^{\mathrm{a}} \\
\end{array}$ & $\begin{array}{c}3.335 \pm \\
0.503^{\mathrm{a}} \\
\end{array}$ & $\begin{array}{c}0.076 \pm \\
0.027^{\mathrm{a}} \\
\end{array}$ & $\begin{array}{l}0.064 \pm \\
0.023^{\text {ef }} \\
\end{array}$ & $\begin{array}{c}2.018 \pm \\
0.272^{\mathrm{b}}\end{array}$ & $=\begin{array}{l}0.002 \pm \\
0.00011^{\mathrm{d}}\end{array}$ & $\begin{array}{c}5.295 \pm \\
0.110^{\mathrm{a}} \\
\end{array}$ & $\begin{array}{c}41.68 \pm \\
3.69^{\mathrm{b}}\end{array}$ \\
\hline & & $\begin{array}{l}110 \pm \\
59.73^{\mathrm{c}} \\
\end{array}$ & $\begin{array}{c}0.584 \pm \\
0.027^{\mathrm{b}}\end{array}$ & $\begin{array}{c}1.931 \pm \\
0.083^{\mathrm{a}} \\
\end{array}$ & $\begin{array}{l}1024 \pm \\
169.2^{\mathrm{bc}}\end{array}$ & $\begin{array}{c}59.11 \pm \\
5.95^{\mathrm{de}}\end{array}$ & & & & & & $\begin{array}{r}10.911 \\
\pm 1.317^{2} \\
\end{array}$ & \begin{tabular}{|c|}
$35.49 \pm$ \\
$3.14^{\mathrm{b}}$ \\
\end{tabular} \\
\hline & & $\begin{array}{l}93 \pm \\
2.58^{\mathrm{c}}\end{array}$ & & $\begin{array}{c}2.104 \pm \\
0.243^{\mathrm{a}} \\
\end{array}$ & $\begin{array}{c}961 \pm \\
139.4^{\mathrm{bc}}\end{array}$ & $\begin{array}{c}80.40 \pm \\
2.72^{\mathrm{c}} \\
\end{array}$ & & $\begin{array}{c}0.04 \pm \\
0.007^{\text {cd }} \\
\end{array}$ & $\begin{array}{l}0.080 \pm \\
0.018^{\text {def }} \\
\end{array}$ & $\begin{array}{l}0.937 \pm \\
0.090^{\mathrm{d}}\end{array}$ & & $\begin{array}{c}6.520 \pm \\
0.183^{\mathrm{a}} \\
\end{array}$ & $\begin{array}{r}130.79 \\
\pm 4.49^{\mathrm{a}} \\
\end{array}$ \\
\hline Starfruit & $\begin{array}{c}0.116 \pm \\
0.076^{\mathrm{a}} \\
\end{array}$ & $\begin{array}{l}21 \pm \\
3.47^{\mathrm{d}}\end{array}$ & $\begin{array}{l}1.298 \pm \\
0.660^{\mathrm{ab}}\end{array}$ & $\begin{array}{l}2.377 \pm \\
0.219^{\mathrm{a}}\end{array}$ & $\begin{array}{c}1053.9 \\
\pm \\
252.1^{\mathrm{bc}}\end{array}$ & $\begin{array}{c}95.14 \pm \\
8.78^{\mathrm{b}}\end{array}$ & $\begin{array}{l}1.101 \pm \\
0.186^{\mathrm{b}}\end{array}$ & $\begin{array}{l}0.152 \pm \\
0.020^{\mathrm{a}}\end{array}$ & $\begin{array}{c}0.043 \pm \\
0.015^{\mathrm{f}}\end{array}$ & \begin{tabular}{|l}
$3.067 \pm$ \\
$0.3530^{5}$
\end{tabular} & $=0.013 \pm$ & $\begin{array}{c}3.855 \pm \\
0.948^{\mathrm{a}}\end{array}$ & $\begin{array}{c}20.53 \pm \\
3.70^{\mathrm{b}}\end{array}$ \\
\hline
\end{tabular}

Values in the same column with different superscript letters represent significant differences between varieties at $\mathrm{p}<0.05$ by Tukey's test, $(\mathrm{n}=3)$

The variability of $\mathrm{Na}$ in fruit samples relies on the soil content [30]. Papaya acts as a fiber and found to be beneficial in the prevention of colon cancer by binding to the cancer causing toxins in the colon and thus keep them away from the healthy colon cells [31]. People who are suffering from hypertension are advisable to consume fruit which contain high $\mathrm{K}$ and low in Na contents [32], [33].

\section{Micro Elements}

The micro minerals composition ( $\mathrm{Al}, \mathrm{Fe}, \mathrm{Zn}, \mathrm{Mn}, \mathrm{Cu}$, $\mathrm{Se}, \mathrm{Pb}, \mathrm{Ba}$ and $\mathrm{Ni}$ ) of local fruits is presented in Table 2. $\mathrm{Al}$ was observed to contain highest concentration compared to others minerals which is in the range between $2.22 \mathrm{mg} / \mathrm{kg}$ to $10.91 \mathrm{mg} / \mathrm{kg}$. ANOVA revealed insignificant difference in $\mathrm{Al}$ content between all the ten samples. Trace elements and heavy metals have some health benefits at lower concentration, but it leads to be toxic at higher levels which cause health risk [27] for an example Al compounds have been shown in animal studies to have effects on the male reproductive system and on the developing embryo.Al in the diet can present from a number of different sources, including the naturally presence in certain foods and crops, food additives and from possible migration from $\mathrm{Al}$ containing food contact materials. The European Food Safety Authority (EFSA) has established the lifelong intake of $\mathrm{Al}$ at a tolerable weekly intake (TWI) of $1 \mathrm{mg} / \mathrm{kg}$ body weight [34]. Guava contains high level of $\mathrm{Al}$ and significantly higher than other fruit samples. This study shows that the highest amount of $\mathrm{Cu}$ was in jackfruit with concentration of $1.73 \mathrm{mg} / \mathrm{kg}$ and the lowest content is recorded in pelam putih $(0.56 \mathrm{mg} / \mathrm{kg})$. Recommended Dietary Allowance (RDA) for $\mathrm{Cu}$ is $900 \mu \mathrm{g}$ /day for both adult male and female [30]. $\mathrm{Cu}$ is vital for human body especially for the nervous and cardiovascular systems, besides that, $\mathrm{Cu}$ plays an important role in thyroid gland metabolism, specifically in hormone production and absorption [35], [36]. The concentration of $\mathrm{Cu}$ was insignificantly different among fruit samples with the range between $0.56 \mathrm{mg} / \mathrm{kg}$ to $1.73 \mathrm{mg} / \mathrm{kg}$.

Elements like $\mathrm{Mn}, \mathrm{Cu}, \mathrm{Fe}, \mathrm{Zn}$ and $\mathrm{Se}$ are essential micro minerals for all forms of life [37]. Banana is reported to contain high level of $\mathrm{Fe}, \mathrm{Zn}$ and $\mathrm{Mn}$ with 3.53 $\mathrm{mg} / \mathrm{kg}, 2.02 \mathrm{mg} / \mathrm{kg}$ and $3.335 \mathrm{mg} / \mathrm{kg}$, respectively. These

minerals are called micro minerals as they are required in amounts less than $100 \mathrm{mg} /$ day [30]. Deficiency of Fe and $\mathrm{Zn}$ in the diet is a global problem and become a great concern in developing countries as people depend more on vegetarian diets. $\mathrm{Zn}$ is responsible for vital immune system meanwhile $\mathrm{Fe}$ is the intrinsic components of hemoglobin, myoglobin and cytochrome and also helps in the metabolic functions [38]. Hence, further study on banana could prove its potential to be a dietary supplement to provide $\mathrm{Zn}$ and $\mathrm{Fe}$, especially for vegetarians. From the results obtained, $\mathrm{Zn}$ concentration was in the range between $0.71 \mathrm{mg} / \mathrm{kg}$ and $3.42 \mathrm{mg} / \mathrm{kg}$. Both rokam and starfruit contained $3.42 \mathrm{mg} / \mathrm{kg}$ and 3.07 $\mathrm{mg} / \mathrm{kg}$ of $\mathrm{Zn}$, respectively and insignificantly different. The $\mathrm{Zn}$ was reported to be lower in pelam padi $(0.98$ $\mathrm{mg} / \mathrm{kg})$, papaya $(0.94 \mathrm{mg} / \mathrm{kg})$, guava $(0.90 \mathrm{mg} / \mathrm{kg})$ and pelam putih $(0.712 \mathrm{mg} / \mathrm{kg})$. Meanwhile, level of $\mathrm{Fe}$ in all samples were reported to be insignificantly different in the ranges between $1.38 \mathrm{mg} / \mathrm{kg}$ and $3.53 \mathrm{mg} / \mathrm{kg}$. It is shown that jackfruit and banana contained high composition of $\mathrm{K}$ and $\mathrm{Fe}$ which play preventive role in hypertension and anemia. Lack of Fe is still becoming a major micro nutrient deficiency worldwide with the major thrust in the developing world. The analysis showed the level of $\mathrm{Fe}$ in all samples were insignificantly different between the range of $1.38 \mathrm{mg} / \mathrm{kg}$ to $3.53 \mathrm{mg} / \mathrm{kg}$. $\mathrm{Fe}, \mathrm{Zn}$, and $\mathrm{Mn}$ are also identified to be potential antioxidants [39] which involve in the strengthening of immune system. Likewise, $\mathrm{Mg}$ and $\mathrm{Zn}$ are proven to prevent muscle degeneration, growth retardation and bleeding disorders [40]. Meanwhile, the variability in Se concentration among local fruits were recorded between $0.002 \mathrm{mg} / \mathrm{kg}$ to $0.344 \mathrm{mg} / \mathrm{kg}$. Rokam recorded highest Se concentration $(0.344 \mathrm{mg} / \mathrm{kg})$ followed by kedondong $(0.232 \mathrm{mg} / \mathrm{kg})$ and banana $(0.002 \mathrm{mg} / \mathrm{kg})$. Starfruit contains lowest level $(0.013 \mathrm{mg} / \mathrm{kg})$ of $\mathrm{Se}$ with insignificantly different. According to [41], Se is a potential mineral which acts as anti-cancer and crucial for immunisation.

It is compulsory to monitor the presence and concentrations of heavy metals, especially in herbs and plants that have health promoting effects as they can cause severe side effects if consumed directly. In 
addition, the levels of heavy metals in plants can be used as an indicator to determine the surrounding pollution. There are various factors that lead to the presence of toxic metals in the environment, such as usage of organic $\mathrm{Hg}$ fungicides and insecticides that contain lead arsenate, poll ution from industrial and traffic emissions, usage of purification mud and agricultural expedients like $\mathrm{Cd}$ containing dung [27]. Pb levels ranged between 0.040 $\mathrm{mg} / \mathrm{kg}$ and $0.207 \mathrm{mg} / \mathrm{kg}$ with rokam contains the highest level while starfruit reported to contain lower concentration. Meanwhile, the content of $\mathrm{Ba}$ was in the range of $0.055 \mathrm{mg} / \mathrm{kg}$ to $0.167 \mathrm{mg} / \mathrm{kg}$, which is revealed by ANOVA to be not significantly different among the samples. According to [42], the maximum daily dietary intake of $\mathrm{Ba}$ for an adult is $0.72 \mathrm{mg} /$ person and the results obtained is within the permitted range. $\mathrm{Ni}$ is found to be an important cofactor to various enzymes by accelerating the normal chemical reactions in our body [43]. Ni is the lowest element content in the samples with the highest value is recorded in starfruit $(0.152 \mathrm{mg} / \mathrm{kg})$, followed by rokam $(0.103 \mathrm{mg} / \mathrm{kg})$. Both jackfruit $(0.076 \mathrm{mg} / \mathrm{kg})$ and banana $(0.076 \mathrm{mg} / \mathrm{kg})$ were insignificantly different. $\mathrm{Ni}$ is exclusively used in the production of stainless steel, metal plating (electric water heaters), coins and batteries. It also has been reported to cause skin allergies and eczema [44]. However, no maximum acceptable limit has been set for $\mathrm{Ni}$ in food. Other samples was observed to be lower in $\mathrm{Ba}$ which in the range between $0.020 \mathrm{mg} / \mathrm{kg}$ and 0.043 $\mathrm{mg} / \mathrm{kg}$ [27] . In the present study, low concentrations of heavy metals ( $\mathrm{Al}, \mathrm{Ba}, \mathrm{Pb}, \mathrm{Ni}$ ) were detected in all samples (Table 2). In [45] reported the presence of heavy metals ( $\mathrm{Cd}, \mathrm{Co}, \mathrm{Fe}, \mathrm{Cu}, \mathrm{Mn}, \mathrm{Zn}, \mathrm{Ni}, \mathrm{Hg}$ and $\mathrm{Pb}$ ) in 42 Chinese herbal medicines are due to the contamination occurred during the air-drying and preservation processes. In [46] mentioned that the heavily polluted soil condition is a significant factor in determining the heavy metal concentration of plant materials used for medicinal purposes [47]. It was discovered the contents of heavy metals correlated with the industrialized regions, and they revealed that the plants grown in an industrialized region had higher level of heavy metals contamination compared to the plants grown in a less- industrialized region.

\section{E. Principal Components Analysis (PCA)}

For the analysis of multivariate data, PCA is generally used to get overview information in the data set. PCA uses the minerals concentration for the quantitative analysis without losing information and extract any information related to local fruit samples [48]-[50]. Information included in variables are explained by the latent variables, also known as components, scores or factor. PCA also helps to plot or visual the concentrated information with many variables into one, two or three dimensions. Most of the information appears on the first dimension and the most shared residual information is shown in the second principal component (PC). Loading plot aids in visualizing the correlation of samples and important variables while score plot helps in finding the similarities and differences between the samples.

\section{F. Macro Elements}

PCA has been applied for the evaluation and classification between local fruits and elements concentration. The information for the above mentioned 13 elements were analyzed using PCA. PC1 covers as much of the variation in the data as possible. PC2 is orthogonal to the $\mathrm{PC} 1$ and covers as much of the remaining variation as possible. The number of significant principal components PCs was selected based on Kaiser Criterion with eigenvalue higher than 1 . The obtained PCA models explained the $75 \%$ and $20 \%$ of the data total variance. The first two components described $95 \%$ variances for all the data. The scatterplot of components $\mathrm{PC} 1$ and $\mathrm{PC} 2$ is shown in Fig. 1. It is interesting to note that in both cases, the score plot allows to discriminate between the samples from different varieties of local fruits. Fig. 1 also reveal that the fruit samples are gathered into three groups: the first group in the top left described the samples which are higher in $\mathrm{Na}$ content (negative PC1,-0.1), the second group focused on the bottom left indicates to contain higher $\mathrm{Ca}$ level (negative PC1 and PC2) and the third group in bottom right classified to samples which have higher $\mathrm{K}$ concentration (positive $\mathrm{PC} 1,0.7$ and 0.1 respectively).
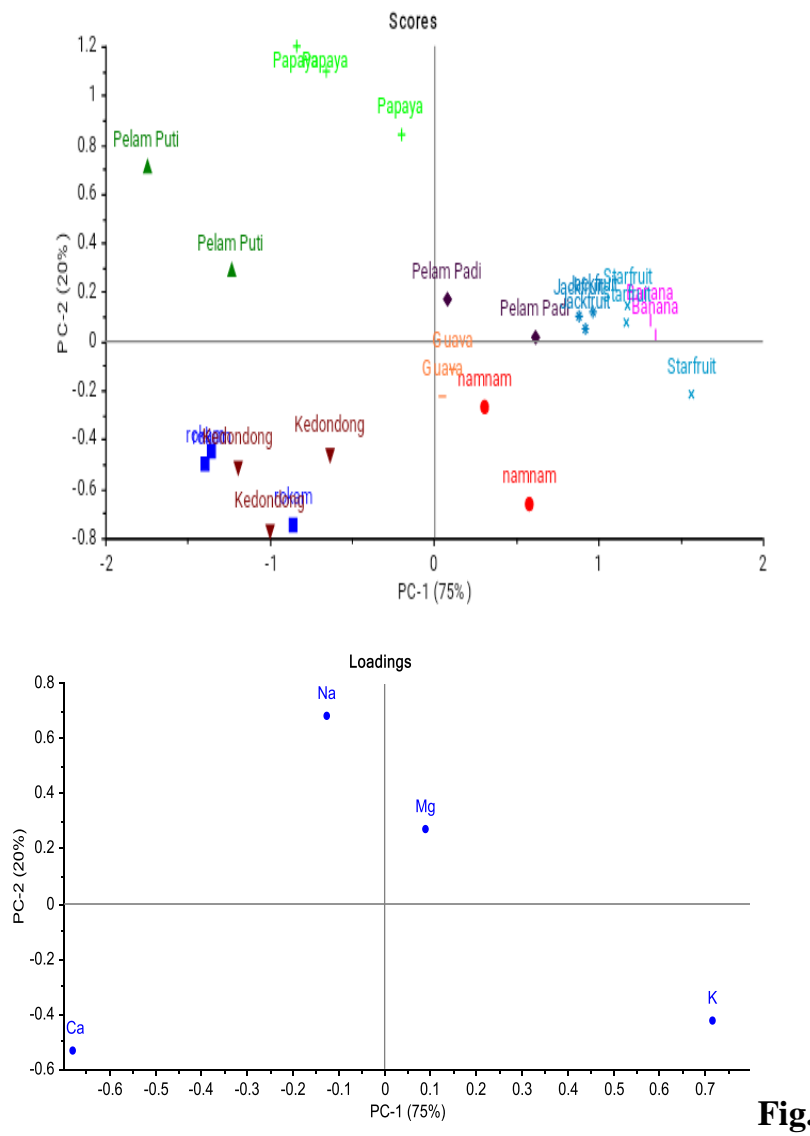

1: Macro elements plot of the first principal components (PC1) versus the second principal component (PC2) for the 


\section{CHEMOMETRIC RESEARCH OF MINERALS AND TRACE ELEMENTS IN SELECTED MALAYSIAN LOCAL FRUITS USING INDUCTIVELY COUPLED PLASMA OPTICAL EMISSION SPECTROSCOPY (ICP-}

OES)

triplicate of $\mathbf{1 0}$ local fruit samples: (a) scores plot and (b) loadings plot

From the plotted graph, pelam putih is observed far away from other samples and opposite to the banana, jackfruit and starfruit. This is due to the lowest $\mathrm{K}$ content among samples which can be referred to the value of each elements in Table 2. Banana, jackfruit and starfruit located between 0.5 and 1.5 on the PC1 while in loadings plot, the element of $\mathrm{K}$ is located between 0.7 and 0.8 on the right $\mathrm{PC} 1$, thus this indicates that, banana, jackfruit and starfruit contain high levels of $\mathrm{K}$ (2347, 2172, 1121 $\mathrm{mg} / \mathrm{kg}$ respectively). Jackfruit, banana, starfruit contained high $\mathrm{Mg}$ with concentration of $247 \mathrm{mg} / \mathrm{kg}, 223 \mathrm{mg} / \mathrm{kg}$ and $95 \mathrm{mg} / \mathrm{kg}$, respectively as they are located at the positive PC1. Samples that are close and near to each other can be classified as a group.

\section{G. Micro Elements}

In order to adequately characterize the varieties and the elements concentration of the local fruits studied, a PCA was performed (Fig. 2). Al was explained positively by the first principal component 1 (PC1) of the PCA, which explains $70 \%$ of the total variability. These parameters were clearly related to guava, papaya, pelam padi and pelam putih. Conversely, the negative axis of PC1 was defined by $\mathrm{Zn}$ and $\mathrm{Cu}$, which were related mainly for the starfruit, rokam and kedondong. PC2 explains $18 \%$ of the total variability, was positively related to the content of minerals such as $\mathrm{Mn}$ and Fe, which is in jackfruit and banana and negatively associated with the kedondong, rokam, starfruit and namnam. Elements $(\mathrm{Ba}, \mathrm{Ni}, \mathrm{Se})$ that are located at the center of loadings plots were contain small amounts of concentration compared to others. These were confirmed by referring to their values in Table 2 .

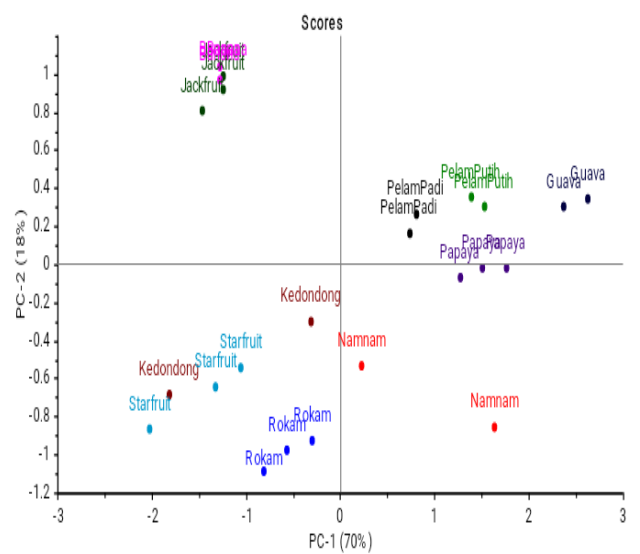

(a)

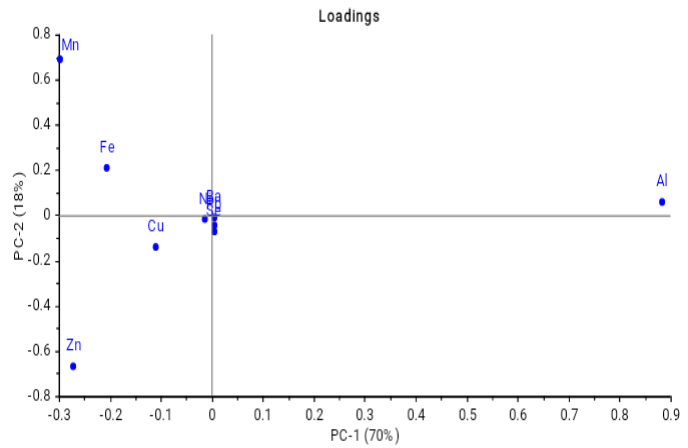

(b)

Fig. 2: Micro elements plot of the first principal components (PC1) versus the second principal component (PC2) for the triplicate of 10 local fruit samples: (a) scores plot and (b) loadings plot

\section{CONCLUSION}

This study contributes to the analyses of mineral concentrations in 10 varieties of Malaysian local fruits. In summary, the results obtained from the analysis of mineral elements, macro and micro elements, the following conclusions were drawn: the maximum $\mathrm{K}$ values recorded for banana and jackfruit were 2347 $\mathrm{mg} / \mathrm{kg}$ and $2172 \mathrm{mg} / \mathrm{kg}$, respectively; Ca showed the highest values in the tests performed on rokam (284 $\mathrm{mg} / \mathrm{kg}$ ) and kedondong (175 $\mathrm{mg} / \mathrm{kg})$. The largest $\mathrm{Mg}$ concentration values were determined in jackfruit (246.82 $\mathrm{mg} / \mathrm{kg}$ ) and banana $(222.56 \mathrm{mg} / \mathrm{kg})$. Maximum values of the element $\mathrm{Na}$ in samples were obtained in papaya $(130.79 \mathrm{mg} / \mathrm{kg})$ and significantly different compared to other samples. Samples that contain higher in $\mathrm{K}$ and lower in $\mathrm{Na}$ concentration are suitable for people who are suffering with hypertension. PCA statistical analysis, using as input concentration values in the macro elements led to very good correlation being obtained in samples of fruit. PC1 had a major influence in the classification of the samples for element $\mathrm{K}$ and $\mathrm{Mg}$. In the groups obtained for PC2, the principal components were influenced by the concentration of the element $\mathrm{Na}$ and $\mathrm{Ca}$ is located opposite to PC1. Analyzed fruit samples showed higher assimilation for micro elements, $\mathrm{Al}, \mathrm{Cu}$, $\mathrm{Mn}, \mathrm{Fe}$ and $\mathrm{Zn}$. Thus, the maximum concentration of $\mathrm{Al}$ $(10.91 \mathrm{mg} / \mathrm{kg})$ in the sample was recorded in guava with significantly different with others sample. The highest concentration of $\mathrm{Cu}$ was recorded in jackfruit (1.727 $\mathrm{mg} / \mathrm{kg})$ and starfruit $(1.298 \mathrm{mg} / \mathrm{kg})$. The element $\mathrm{Mn}$ showed high concentration for samples: banana and jackfruit (3.335 mg/kg and $3.048 \mathrm{mg} / \mathrm{kg}$ respectively). A greater assimilation of $\mathrm{Zn}$ in the samples were recorded in rokam $(3.417 \mathrm{mg} / \mathrm{kg}$ ) and starfruit $(3.067 \mathrm{mg} / \mathrm{kg})$. The heavy metals concentrations of the micro elements studied did not exceed the allowable limits. Rokam is a kind of underutilized fruit that shown to have high $\mathrm{Ca}$ content compare to others fruit. Meanwhile, banana, jackfruit, rokam, starfruit and guava contain high potassium content respectively. 


\section{ACKNOWLEDGMENT}

The authors would like to thank the Ministry of Higher Education, Malaysia for funding this research through Niche Research Grants Scheme (USIM/NRGS_P5/ISI/8405/52113).

\section{REFERENCES}

1. H. M. C. Ramona, H. M. Gabriel, N. Petru, S. Radu, N. Adina, and S. Ducu, "The monitoring of mineral elements content in fruit purchased in supermarkets and food markets in Timisoara, Romania," Annals of Agricultural and Environmental Medicine, 21(1), 2014, pp. 98-105.

2. E. B. Grzesik, and A. J. Kolon, "Leaching of cadmium and lead from dried fruits and fruit teas to infusions and decoctions," Journal of Food Composition and Analysis, 21(4), 2008, pp. 326-331.

3. H. N. E. Obong, H. O. Okudu, and U. V. Asumugha, "Nutrient and phytochemical composition of two varieties of Monkey kola (Cola parchycarpa and Cola lepidota): An underutilised fruit," Food Chemistry, 193, 2016, pp. 154159.

4. A. Waxman, "Prevention of chronic diseases: WHO global strategy on diet, physical activity and health," Food Nutrition Bulletin, 24(3), 2003, pp. 281-284.

5. World Health Organization (WHO), Global tuberculosis control: Epidemiology, strategy, financing: WHO report 2009. Geneva: WHO, 2009.

6. M. Isabelle, B. Lan, M. Thiam, W. Koh, D. Huang, and C. Nam, "Antioxidant activity and profiles of common fruits in Singapore," Food Chemistry, 123(1), 2010, pp. 77-84.

7. J. N. Hall, S. Moore, S. B. Harper, and J. W. Lynch, "Global variability in fruit and vegetable consumption," American Journal of Preventive Medicine, 36(5), 2009, pp. 402-409.

8. H. Altundag, and M. Tuzen, "Comparison of dry, wet and microwave digestion methods for the multi element determination in some dried fruit samples by ICP-OES," Food and Chemical Toxicology, 49(11), 2011, pp. 28002807.

9. J. Pomerleau, K. Lock, \& M. McKee, "The burden of cardiovascular disease and cancer attributable to low fruit and vegetable intake in the European Union: Differences between old and new Member States," Public Health Nutrition, 9(5), 2006, pp. 575-583.

10. U. Ramakrishnan, "Prevalence of micronutrient malnutrition worldwide," Nutrition Reviews, 60(suppl 5), 2000, pp. S46-S52.

11. J. D. Bogden, and J. M. Oleske, "The essential trace minerals, immunity, and progression of HIV-1 infection," Nutrition Research, 27(2), 2007, pp. 69-77.

12. T. Mahmood, F. Anwar, T. Iqbal, and I. Ahmad, "Mineral composition of strawberry, mulberry and cherry fruits at different ripening stages as analyzed by inductively coupled plasma-optical emission," Journal of Plant Nutrition, 35(1), 2013, pp. 111-122.

13. A. Duran, M. Tuzen, and M. Soylak, "Trace element levels in some dried fruit samples from Turkey," International Journal of Food Sciences and Nutrition, 59(7-8), 2008, pp. 581-589.

14. S. W. Yan, R. Ramasamy, and N. B. Mohamed, "A comparative assessment of nutritional composition, total phenolic, total flavonoid, antioxidant capacity, and antioxidant vitamins of two types of Malaysian underutilized fruits (Averrhoa Bilimbi and Averrho carambola)," International Journal of Food Properties, 16(6), 2013, pp.1231-1244.

15. A. Rukayah, Buah-Buahan Nadir Semenanjung Malaysia. Kuala Lumpur: Dewan Bahasa dan Pustaka, 1992.
16. E. H. K. Ikram, K. H. Eng, A. M. M. Jalil, A. Ismail, S Idris, A. Azlan, H. S. M. Nazri, N. A. M. Diton, and R. A M. Mokhtar, "Antioxidant capacity and total phenolic content of Malaysian underutilized fruits," Journal of Food Composition and Analysis, 22(5), 2009, pp. 388-393.

17. M. S. Dundar, and H. Altundag, "Investigation of heavy metal contaminations in the lower Sakarya river water and sediments," Environmental Monitoring and Assessment, 128(1-3), 2007, pp. 177-181.

18. M. Bakircioglu, O. P. Carvalho, M. Khurshid, J. J. Cox, B. Tuysuz, T. Barak, S. Yilmaz, O. Caglayan, A. Dincer, A. K. Nicholas, and O. Quarrell, "The essential role of centrosomal NDE1 in human cerebral cortex neurogenesis," American Journal of Human Genetics, 88(5), 2011, pp. 523-535.

19. G. Baskaran, N. A. Masdor, M. A. Syed, and M. Y Shukor, "An inhibitive enzyme assay to detect mercury and zinc using protease from coriandrum sativum," Scientific World Journal, 2013, 2013, pp. 1-7.

20. G. Tyler, and Y. S. Jobin, ICP-OES, ICP-MS and AAS techniques compared. 1995, Available: http://www.horiba.com/fileadmin/uploads/Scientific/Down loads/OpticalSchool_CN/TN/ICP/ICP-OES_ICP-

MS_and_AAS_Techniques_Compared.pdf.

21. M. C. Pereira, W. Boschetti, R. Rampazzo, P. G. Celso, P. F. Hertz, A. D. O. Rios, M. Vizzotto, and S. H. Flores, "Mineral characterization of native fruits from the southern region of Brazil," Food Science and Technology, 34(2), 2014, pp. 258-266.

22. Association of Official Agricultural Chemists (AOAC) International, AOAC international guidelines for laboratories performing microbiological and chemical analyses of food and pharmaceuticals: An aid to interpretation of ISO/IEC 17025: 2005. Maryland: AOAC International, 2006.

23. M. S. Rabeta, and R. N. Faraniza, "Total phenolic content and ferric reducing antioxidant power of the leaves and fruits of Garcinia atrovirdis and Cynometra cauliflora," International Food Research Journal, 20(4), 2013, pp. 1691-1696.

24. P. B. Ayoola, and A. Adeyeye, "Phytochemical and nutrient evaluation of carica papaya (pawpaw ) leaves," International Journal of Research and Reviews in Applied Sciences, 5(3), 2010, pp. 325-328.

25. P. Leterme, A. Buldgen, F. Estrada, and A. M. Londoño, "Mineral content of tropical fruits and unconventional foods of the Andes and the rain forest of Colombia," Food Chemistry, 95(4), 2006, pp. 644-652.

26. E. A. R. Assirey, "Nutritional composition of fruit of 10 date palm (Phoenix dactylifera L.) cultivars grown in Saud Arabia," Journal of Taibah University for Science, 9(1), 2015, pp. 75-79.

27. R. Bhat, K. Kiran, A. B. Arun, and A. A. Karim, "Determination of mineral composition and heavy metal content of some nutraceutically valued plant products," Food Analytical Methods, 3(3), 2010, pp. 181-187.

28. H. Okudu, and S. Onyendi, "Evaluation of the chemical and sensory attributes of juice developed from cashew and jackfruit pulp," African Journal of Food Science and Technology, 7(5), 2016, pp. 94-99.

29. S. B. Swami, N. J. Thakor, P. M. Haldankar, and S. B. Kalse, "Jackfruit and its many functional components as related to human health: A review. Comprehensive Reviews in Food Science and Food Safety, 11(6), 2012, pp. 565-576. 


\section{CHEMOMETRIC RESEARCH OF MINERALS AND TRACE ELEMENTS IN SELECTED MALAYSIAN LOCAL FRUITS USING INDUCTIVELY COUPLED PLASMA OPTICAL EMISSION SPECTROSCOPY (ICP- OES)}

30. M. A. Sajib, S. Jahan, M. Khan, and B. Saha, "Nutritional evaluation and heavy metals content of selected tropical fruits in Bangladesh,” International Food Research Journal, 21(2), 2014, pp. 609-615.

31. B. Parni, and Y. Verma, "Biochemical properties in peel pulp and seeds of carica papaya," Plant Archives, 14(1), 2014, pp. 565-568.

32. P. Mariyam, and V. Mary, "Nutritional analysis (macronutrients, potassium and iron content) of four palm date varieties (Phoenix dactylifera L.) and study of consumption pattern among Muslim and Maharashtrian community," Journal of Food Processing and Beverages, 3(1), 2014, pp. 1-9.

33. A. M. Martín-Sánchez, S. Cherif, J. Ben-Abda, X. BarberVallés, J. A. Pérez-álvarez, and E. Sayas-Barberá, "E. Phytochemicals in date co-products and their antioxidant activity," Food Chemistry, 158, 2014, pp. 513-520.

34. BfR, BfR Health Assessment No. 034: Aluminium in apple juice: no storing of fruit juice in aluminium tanks. 2008, Available:

http://www.bfr.bund.de/cm/349/aluminium_in_apple juice_no_storing_of_fruit_juice_in_aluminium_tan ks.pdf.

35. S. S. Abdrabo, G. Grindlay, L. Gras, and J. Mora, "Multielement analysis of spanish date palm (phoenix dactylifera 1.) by inductively coupled plasma-based techniques discrimination using Multivariate Statistical Analysis," Journal of Food Analytical Method, 8(5), 2015, pp. 12681278.

36. S. B. Swami, N. J. Thakor, P. M. Haldankar, and S. B. Kalse, "Jackfruit and its many functional components as related to human health: A review," Comprehensive Reviews in Food Science and Food Safety, 11(6), 2012, pp. 565-576.

37. S. Saracoglu, M. Tuzen, and M. Soylak, "Evaluation of trace element contents of dried apricot samples from Turkey," Journal of Hazardous Materials, 167(1-3), 2009, pp. 647-652.

38. S. Hemalatha, K. Platel, and K. Srinivasan, "Zinc and iron contents and their bioaccessibility in cereals and pulses consumed in India," Food Chemistry, 102(4), 2007, pp. 1328-1336.

39. H. S. Talwar, G. J. Fisher, V. A. Harris, and J. J. Voorhees, "Agonist-induced hydrolysis of phosphoinositides and formation of 1, 2-diacylglycerol in adult human keratinocytes," Journal of Investigative Dermatology, 93(2), 1989, pp. 241-245.

40. R. Chaturvedi, Y. Cheng, M. Asim, F. I. Bussière, H. Xu, A. P. Gobert, A. Hacker, R. A. Casero, and K. T. Wilson, "Induction of polyamine oxidase 1 by Helicobacter pylori causes macrophage apoptosis by hydrogen peroxide release and mitochondrial membrane depolarization," Journal of Biological Chemistry, 279(38), 2004, pp. 40161-40173.

41. W. Al-Shahib, and R. J. Marshall, "Fatty acid content of the seeds from 14 varieties of date palm Phoenix dactylifera L.," International Journal of Food Science and Technology,38(6), 2003, pp. 709-712.

42. World Health Organization (WHO), Cancer pain relief: With a guide to opioid availability. Geneva: WHO, 1996.

43. R. Hänsch, and R. R. Mendel, "Physiological functions of mineral micronutrients $(\mathrm{Cu}, \mathrm{Zn}, \mathrm{Mn}, \mathrm{Fe}, \mathrm{Ni}, \mathrm{Mo}, \mathrm{B}, \mathrm{Cl})$," Current Opinion in Plant Biology, 12(3), 2009, pp. 259266.

44. L. Jorhem, B. Sundström, J. Engman, C. Åstrand-Yates, and I. Olsson, "Levels of certain trace elements in beef and pork imported to Sweden," Food Additives and Contaminants, 13(7), 1996, pp. 737-745.

45. P. K. Wong, K. C. Lam, and C. M. So, "Removal and recovery of $\mathrm{Cu}$ (II) from industrial effluent by immobilized

cells of Pseudomonas putida II-11," Applied Microbiology and Biotechnology, 39(1), 1993, pp. 127-31.

46. L. Kabelitz, "Heavy metals in herbal drugs," European Journal of Herbal Medicine, 4, 1998, pp. 25-29.

47. M. Januz, W. Danutra, K. Jerzy, R. Robart, L. Krysztof, and C. Jerzy, "The occurrence of $\mathrm{Pb}, \mathrm{Cd}, \mathrm{Cu}, \mathrm{Mn}, \mathrm{Ni}, \mathrm{Co}$, and $\mathrm{Cr}$ in selected species of medicinal plants in Poland," Bromatol Toksypol, 28, 1994, pp. 363-368.

48. M. K. A. Kamarudin, M. E. Toriman, and N. H. Sulaiman, "Classification of tropical river using chemometrics technique: Case study in Pahang River, Malaysia," Malaysian Journal of Analytical Sciences, 19(5), 2015, pp. 1001-1018.

49. A. Azid, H. Juahir, M. E. Toriman, A. Endut, M. K. A. Kamarudin, A. Rahman, and M. Nordin, "Source apportionment of air pollution: A case study in Malaysia." Jurnal Teknologi, 72(1), 2015, pp. 83-88.

50. K. H. Esbensen, D. Guyot, F. Westad, and L. P. Houmoller, Multivariate Data Analysis: In Practice: An Introduction to Multivariate Data Analysis and Experimental Design. Esbjerg: Aalborg University, 2002. 